\title{
Does transformational leadership encourage teachers' use of digital learning materials
}

Citation for published version (APA):

Vermeulen, M., Van Acker, F., Kreijns, K., \& Van Buuren, H. (2015). Does transformational leadership encourage teachers' use of digital learning materials. Educational Management, Administration \& Leadership, 43(6), 1006-1025. https://doi.org/10.1177/1741143214535749

\section{DOI:}

$10.1177 / 1741143214535749$

Document status and date:

Published: 01/11/2015

Document Version:

Peer reviewed version

\section{Document license:}

CC BY-NC-ND

Please check the document version of this publication:

- A submitted manuscript is the version of the article upon submission and before peer-review. There can be important differences between the submitted version and the official published version of record. People interested in the research are advised to contact the author for the final version of the publication, or visit the DOI to the publisher's website.

- The final author version and the galley proof are versions of the publication after peer review.

- The final published version features the final layout of the paper including the volume, issue and page numbers.

Link to publication

\section{General rights}

Copyright and moral rights for the publications made accessible in the public portal are retained by the authors and/or other copyright owners and it is a condition of accessing publications that users recognise and abide by the legal requirements associated with these rights.

- Users may download and print one copy of any publication from the public portal for the purpose of private study or research.

- You may not further distribute the material or use it for any profit-making activity or commercial gain

- You may freely distribute the URL identifying the publication in the public portal.

If the publication is distributed under the terms of Article 25fa of the Dutch Copyright Act, indicated by the "Taverne" license above, please follow below link for the End User Agreement:

https://www.ou.nl/taverne-agreement

Take down policy

If you believe that this document breaches copyright please contact us at:

pure-support@ou.nl

providing details and we will investigate your claim.

Downloaded from https://research.ou.nl/ on date: 26 Apr. 2023 


\section{Does Transformational Leadership Encourage Teacher's Use of Digital}

Learning Materials?

Marjan Vermeulen ${ }^{1}$, Frederik Van Acker ${ }^{2}$, Karel Kreijns ${ }^{3}$ and Hans van Buuren ${ }^{2}$

${ }^{1}$ Teacher University, Open University Nederland and KPC Group Netherlands

${ }^{2}$ Faculty of Psychology, Open University Nederland

${ }^{3}$ Scientific Centre of Teacher Research (LOOK),

Open University Nederland

\section{Corresponding author:}

Marjan Vermeulen, Teacher University, Open

University Netherlands, Valkenburgerweg 177,

6419AT Heerlen, Netherlands

Email: marian.vermeulen@ou.nl 


\section{Abstract}

To gain insight into how to promote teachers' use of digital learning materials (DLMs) in their pedagogical practices we adopted the Integrated Model of Behavior Prediction to investigate the relationships between organizational and teacher related variables. A representative sample of 772 teachers from primary, secondary or vocational education took part in a survey study. Conjectured combinations of direct and indirect relationships between the variables were tested for the best model fit with structural equation modeling. The results suggest that a model with mediating relations from leadership through ICT policy and professional development activities to the variables self-efficacy, attitude and social norm, combined with direct relations from leadership to the latter has the best fit for predicting teachers' intention to use DLMs.

\section{Keywords:}

Digital learning materials; transformational leadership; Integrated Model for Behavior Prediction; ICT policy; professional development.

\section{Introduction}

The introduction of information and communication technologies (ICTs) in educational practice can be considered as a form of innovative behavior among teachers. Indeed, its use is currently still not an everyday routine in the school (Tondeur et al. 2007). Therefore it requires teachers to acquire new skills and competencies before it can actually become a daily routine (Loogma et al., 2012). Moreover, the use of ICT may cause other problems to solve in teachers' daily work performance, than the ones they have been accustomed to until now.

Implementation of new technologies can change every day routines substantially. Such a change can be understood as an innovation, which in turn requires innovative behavior of employees. From research on innovations in education it is known that changes in teaching practice only flourish if the various actors at different levels (individual teacher, team and school level to national policy) have a joint vision on the subject (Hargreaves and Fink, 2006; Kennisnet, 2011). Availability and accessibility of a new technology alone is not sufficient to encourage the educational use of it (Van Kessel et al., 2004; Tondeur et al., 2010). Even when all possible conditions for the use of ICT have been created, teachers' ICT usage has been found to be very limited (Yang and Huang, 2008). This implies that for the implementation of ICT in educational practice, additional incentives should be developed to achieve the actual desired innovation. In the context of the "Wikiwijs initiative" (an infrastructure for the educational field to share digital learning materials in the Netherlands (OCW, 2010)), we conducted a questionnaire study in primary, secondary and vocational education. The aim of this study was to explore teacher related variables in relation to their intention to use digital learning materials (DLMs) as a particular form of ICT - in their pedagogical practices. In order to promote the use of DLMs it is important to gain more insights in the relationships between these teacher related variables and school organizational variables. In Wikiwijs, the definition of DLMs was broadly formulated, namely all 
forms of digital objects that can be used in education, including images, as well as digital texts, curricular or integrated methods and everything in between (Van Buuren et al., 2010). DLMs were therefore in this article also operationalized broadly.

Research has shown that human behavior is influenced by both the environment as well as individual factors such as motivation and capacity (see for instance Leithwood et al., 2002) and that this also applies to the educational use of ICT (Pelgrum, 2001; Law and Chow, 2008). For a conceptual model to have sufficient predictive value, it should thus encompass environmental as well as individual variables. The Integrated Model for Behavior Prediction (IMBP, see Fishbein 2000) contains a number of critical factors that helps to determine important variables in relation to the application of DLMs in educational practice. IMBP is a combination of the Theory of Planned Behavior (Ajzen, 1991), Social Cognitive Learning Theory (Bandura, 1997) and the Health Belief Model (Janz and Becker, 1984). In IMBP three individual variables are placed at the core of the model. These are labeled proximal variables (they include self-efficacy, attitude and subjective norm) and are supposed to have a short distance to behavioral intention, and thus, can be seen as direct antecedents of intention. Distal variables, in IMBP, are more 'distant' from intention and their influence on intention is mediated through one or several proximal variables. Distal variables can be more or less distal, and form a chain of mediating relationships through which the outcome variable, a particular type of behavior is influenced.

This current study builds on earlier research on the intention of teachers to use DLMs, in which the IMBP was first tested for the topic of DLMs (Van Acker et al., 2011; Vermeulen et al., 2012; Kreijns et al., 2012). These previous studies have focused mainly on individual determinants of behavior, and concluded that the intention of teachers to use DLMs was largely explained by three variables: selfefficacy, attitude and to a lesser extent subjective norm regarding DLM usage. The latter can possibly be explained by the finding that teachers experience only limited pressure to get started with DLMs. For a more detailed description of IMBP and the variables used, we refer to the studies cited above.

The present study expands IMBP by including school organizational variables encompassing transformational leadership, school ICT policy and ICT professional development activities. Although several empirical studies have shown the importance of self-efficacy, attitude and subjective norm, it is yet unclear how these variables are influenced by variables at other levels in the context of using DLMs. First, some models suggest direct relations between independent variables (e.g., transformational leadership (Pieterse et al., 2010) and behavior. Second, other models suggest that psychological variables (such as different forms of motivation) mediate the relationship between the independent variables and behavioral intention (see for instance, Leithwood and Jantzi, 2006). More recently, the tested models have become more complex in the sense that a chain of variables can be determined that influence direct and/or indirect behavior (e.g., Thoonen et al., 2011; Sang et al., 2011).

Moreover, it is still unclear which causal model underlies these structural relationships between variables at the organizational or teacher level. For the present study we formulated the following research question: To what extent does school leadership behavior, expressed through a manifest school ICT-policy, affect professional development in ICT applications, as well as teachers' self- 
efficacy, attitude, subjective norm and teachers' intention to use DLMs? In search of the best model fit, we compare three different models. All three models are based on IMBP, but they differ in the degree to which direct and indirect relationships between the variables are allowed. The first model allows only fully mediated relations between the organizational and the teacher variables. The second model includes direct relations between leadership and all the organizational variables and the teacher variables. The last model allows - in combination with the mediating relations of the organizational variables in model 2 - direct relations between the leadership dimensions on the one hand and the three proximal variables (teacher variables) on the other hand.

\section{Theoretical framework and measurements on the role of leadership and integrating ICT}

The aim of this study is to test whether the proximal variables from the IMBP (self-efficacy, attitude and subjective norm) are influenced by school leadership. Moreover the impact of ICT policy and professional development activities with regard to ICT is tested and it will be determined to what extent these latter variables mediate the relationship between leadership and the proximal variables, and the intention to use DLMs. However, the problem is that existing and validated instruments are not available for most of the variables in our model. The reason for this is that specific behavior rather than generic behavior has to be measured and the likelihood to find validated instruments for specific behaviors is rather low. In fact it is almost near to impossible to find instruments that other scholars have developed because their studies may focus on other types of specific behavior. But, it is possible to find instruments that can act as a template. In general, adapting existing instruments and adding new items in order to construct appropriate IMBP measures is a normal and necessary procedure according to Fishbein and Ajzen (2010). To support scientists in constructing new instruments, Fishbein and Ajzen (2010) have included an Appendix that delineates how to do this. The scale for measuring intention to use DLMs was constructed eventually with four items, following the guidelines by Ajzen (2010) and Fishbein and Ajzen (2010). See Table 2 which presents an overview of all the items that belong to the various instruments.

\section{Proximal variables}

The variable self-efficacy is derived from the definition of Bandura who formulated this concept as follows: "beliefs in one's capabilities to organize and execute the courses of action required producing given attainments" (Bandura, 1997, p. 3). In other words, self-efficacy is the belief of someone that he can perform a particular behavior and can deliver a satisfactory performance. Self-efficacy here is the degree to which someone is convinced that he can successfully use DLMs in class under certain inhibiting or stimulating conditions. Self-efficacy is often seen as a motivational factor and known as an 
important mediating variable between organizational characteristics and (the intention to express) certain behavior (Gong et al., 2009; Thoonen et al., 2011). In this research we choose an earlier Dutch validated instrument from Geijsel and colleges (2009) that is in line with the definition used in the IMBP.

Attitude is defined as a general feeling of sympathy or antipathy with respect to the use of DLMs. Ajzen (1991) formulated attitude as follows "the degree to which a person has a favorable or unfavorable evaluation or appraisal of the behavior in question" (p. 188). The relation between attitude and the use of ICT in pedagogical practice is found in a number of studies (Law and Chow, 2008; Sang et al., 2011). In our earlier research (Kreijns et al. 2012; Van Acker et al. 2011; Vermeulen et al 2012) we constructed a valid attitude scale for our context following the guidelines of Fishbein and Ajzen (2010).

Subjective norm consists of the experienced psychological pressure to perform certain behavior, such as using DLMs in class. This pressure is usually exerted by the teacher's key stakeholders. According to Ajzen (1991) subjective norm refers to "the perceived social pressure to perform or not to perform the behavior" (p. 188). This variable is measured with one single item, which is not uncommon in IMBP, see for example, the study of Hagger and Armitage (2004).

\section{Distal variables}

\section{Transformational leadership}

According to IMBP distal variables exert a certain degree of influence on behavior (or intention) through the proximal variables. In this study we take leadership as an important environmental factor in influencing the behavior of teachers, and thus as a distal variable. Leadership is seen as an essential element in sustainable educational development (Hargreaves and Fink, 2006; Timperley et al., 2007). Differentiation in leadership behavior seems to be essential for optimal employee behavior. For instance leadership communication and giving meaning by teachers have important consequences for school innovations (Cosner, 2011). In addition, various types of leaders and leadership styles have been distinguished in previous studies (see for instance Bush and Glover, 2003; Quinn et al., 1996). In this study, we opted for transformational leadership because this type of leadership is explicitly directed at the developmental capacity and the personal commitment of employees in an organization as well as its goals to increase productivity (Bass and Avolio, 1994).

Transformational leadership is defined as a style of leadership that transforms employees to rise above their self-interest by altering their morale, ideals, interests, and values, motivating them to perform better than initially expected (Bass, 1985; Yukl, 1998). In other words transformational leadership refers to a set of behaviors of leaders, which should lead to higher motivation and an increased performance of employees (Geijsel et al., 1999, 2009; Leithwood and Jantzi, 2006). In research on transformational leadership within school organizations, three dimensions of this type of leadership have been identified: vision development, individual consideration, and intellectual stimulation (Geijsel et al., 2009). These three dimensions are included as variables in this study. 
The empirical research on transformational leadership in relation to individual behavior has some contradictory results (Aryee et al., 2012). This, can be explained by the perception of employees regarding leadership behavior (Aryee et al., 2012). Transformational leaders motivate their employees by articulating a vision and mission in terms of the values these leaders represent (Gronn, 2000). Visionary and inspiring communication structures the attention and gives meaning to the actions of the employees. In other words, by communicating the vision and purpose of the organization or organizational unit, employees will develop a more common frame of reference (Cosner, 2011). In the case of ICT, for example, leaders will thus, by communicating a clear vision on the use of DLMs convince teachers of the usefulness and necessity of the use of DLMs. Usefulness and necessity of certain behavior is in the IMBP measured with the variable attitude (usefulness) and subjective norm (necessity). Despite this theory, results show few effects of transformational leadership on actual employee behavior (Aryee et al., 2012; Leithwood and Jantzi, 2006). An explanation is the lack of communication about the vision and a lack of focus on achieving the organizational goals leading to different perceptions by employees (Aryee et al., 2012). This lack of common sense making to the purpose of the organization and its policies (Cosner, 2011) creates a situation, in which individual support and intellectual stimulus miss a clear purpose, no positive attitude and no sense of subjective norm towards the behavior is developed.

Another reported problem within educational organizations is the limited impact of transformational leadership on student outcomes (Marks and Printy, 2003; Leithwood and Jantzi, 2006; Robinson et al., 2008). Again, one of the explanations given for the limited impact on student outcomes was the lack of focus provided by the leader on the organizational goals in daily practice. Marks and Printy (2003) therefore argued in favor of integrating transformational leadership and educational leadership, the latter being leadership that is focused on improving student outcomes in the daily routine. Robinson et al. (2008) added the dimension of involving, promoting and participating in teacher professionalization as a more important leadership dimension than goal setting with regard to student outcomes. In this research the scales for the three dimensions of transformational leadership developed for the Dutch educational context by Geijsel et al. (2009) were included. The vision scale focuses on keeping the vision alive in all kind of situations. The individual consideration scale focuses on emotional support and explicit appreciation for teachers' own initiative. Individual consideration has to be understood from the perspective that a transformative leader acknowledges the individual aspirations, actions, beliefs and values rather than privileging the individual. Such acknowledgement implicates that the transformative leader is giving autonomy and support to the individual. This support can be informational, emotional, instrumental and appraisal (see Van der Heijden, 2003). The items in Geysel's et al scale for individual consideration reflect in particular the appraisal en emotional support. (see Tabel 2).Informational and instrumental support are more dominant reflected in the scale for intellectual stimulation. The intellectual stimulation scale, finally, focuses on learning development experimenting and challenges.

From various findings, we can expect that the relationship between organizational conditions, such as the dimensions of transformational leadership, ICT-policy and ICT related professional development activities on the one hand and the daily practice and use of new technologies on the 
other hand is more complex than has been concluded in previous research, where direct relationships between organizational conditions and employee behavior have been suggested. In this study, we consider different models in order to find a model that has the best prediction on teachers' intention to use DLMs in pedagogical practices.

\section{ICT policy}

Because transformational leadership per se seemed too unfocused to implement the desired organizational outcomes, adding clear goals could be important. Indeed, clear goals formulated in a clear ICT policy are important factors for stimulating teachers using ICT in the classroom (Tondeur et al., 2007). Based on qualitative case studies Vanderlinde et al., (2012) found important relationships between leadership and the quality of the schools' ICT policy. The quality of the ICT policy revealed to be important for the implementation and integration of ICT into the curriculum. International research pointed out that school leadership, development, and implementation of policies influences the effectiveness of schools as measured by student performance (OECD, 2010). Based on these findings, hypothesis 1 can be formulated: The three dimensions of transformational leadership, namely vision (1a), individual support (1b) and intellectual stimulus (1c) are related to the degree of implementation of ICT policy within the school.

In different studies (Vanderlinde et al., 2012; Tondeur et al., 2008), influencing factors on the teachers' ICT use were situated at the school level. One of the important factors at the school level included the presence of an ICT policy. No instrument for this variable was yet at hand. Therefore, based on items from Tondeur et al. (2008), two items (see Table 2) were used to construct the instrument. We believe that these two items capture the core findings of the study of Tondeur et al. (2008). Based on these findings, we formulate hypothesis 2: ICT policy affects the self-efficacy (2a), attitudes (2b), and subjective norm (2c), which in turn affect the intention to use DLMs in the classroom.

\section{Professional development activities regarding ICT}

Professional development activities are important in relation to teachers' use of ICT (Pelgrum, 2001; Tondeur et al., 2008; Loogma et al., 2012). Transformational leadership is related to teachers attending professional development activities (Thoonen et al., 2011; Geijsel et al., 2009). To date, no research has investigated the relation between transformational leadership, ICT policy and professional development. ICT policy should, among others, include employee professionalization plans for the field of ICT (Van Kessel et al., 2004). Therefore we assume that the relationship between transformational leadership and the professional development activities on the intention to use DLMs is mediated by ICT policy (hypothesis 3). To measure professional development activities a validated instrument from Kwakman (1999) was used. This instrument measures formal and more informal activities regarding CPD. The instrument is made more context specific by adding ICT of DLMs in the items.

At the individual level of teacher professionalization, taking formal computer training plays an important role in whether or not teachers use ICT in their classes (Mumtaz, 2000). The influence of 
attending professionalization activities on teaching behavior was found to be mediated by self-efficacy and motivation (Geijsel et al., 2009). Based on these findings hypothesis 4 can be formulated: professionalization influences self-efficacy (4a), attitude (4b), and subjective norm (4c) regarding the intention of teachers to use DLMs in their teaching practices. These four hypotheses combined, form our first model, shown in Figure 1.

In figure 1 the implementation for the use of DLMs in the IMBP is drawn. According to Fishbein and Ajzen (2010), the effects of the environmental variables are fully mediated by the proximal variables. In other words, we expect that the three dimensions of transformational leadership, both through the ICT policy of the school, via the professional development activities, influence selfefficacy, attitude and subjective norm. In this figure, the distal variables influence the intention to use DLMs through each of the more proximal variables. Figure 1 shows the factors examined here at the individual level of the teacher and the perceived ambient level based on the principles of the IMBP. The above-formulated hypotheses with numbers are displayed in the model.

\section{INSERT FIGURE 1 ABOUT HERE}

\section{Alternative models}

Different researchers have reported inconsistent findings regarding the link between transformational leadership and employee behavior (Pieterse et al., 2010). Some studies have reported direct effects of leadership characteristics on employee motivation or behavior (for instance Leithwood and Jantzi, 2006; Leithwood and Mascall, 2008) while other studies found mediating variables between the environmental and some of the proximal variables (Thoonen et al., 2011). Gong and colleagues (2009) speculated on several reasons for these inconsistent findings, including the need to learn more about the mechanisms underlying the effects of transformational leadership on employee behavior. The mechanisms underlying these inconsistencies have not yet been empirically tested (Ayree et al., 2012; Marks and Printy, 2003). By comparing different relational models based on the same variables used in model 1, we hope to add some new insights on teachers' intention to use DLMs in daily practice.

Model 2 is an expansion of model 1 on the direct relations of the transformative leadership dimensions on the distal variable professionalization activities. The paths $6 \mathrm{a}, 6 \mathrm{~b}$ and $6 \mathrm{c}$ are based on literature on professionalization activities in educational organizations that gave empirical evidence for the enhancement of professionalization by some dimensions of transformational leadership (Stoll et al., 2006; Thoonen et al., 2011). In addition, one study found a mediating role for professional development activities between transformational leadership and teachers' self-efficacy (Geijsel et al., 2009). Thus model 2 was tested with the hypotheses that the three transformational leadership dimensions affect professional development activities regarding ICT directly in addition to the indirect effect through ICT policy (6a, b and c). 


\section{INSERT FIGURE 2 ABOUT HERE}

Model 3 is based on research that demonstrates direct relationships between transformational leadership and all kinds of behavior of employees (for example Chen et al., 2012), because until now, little research on transformational leadership dimensions and the use of ICT has been conducted. . In this third model the direct relationships (7a,b,c, 8a,b,c and 9a,b,c,) between the transformational leadership dimensions and the proximal variables are tested in combination with the mediating relationships as presented in model 2 .

INSERT FIGURE 3 ABOUT HERE

\section{Method}

Data collection and response

The data was collected in two rounds (2010 and 2011), in which different questionnaires were submitted. In total, 772 teachers, teaching in primary, secondary, and vocational education from a research panel of TNS NIPO (professional organization for data gathering in the Netherlands) filled in the combination of the two questionnaires. The response is presented in Table 1 and exhibits a distribution that is representative for the characteristics of the population of Dutch teachers.

\section{INSERT TABLE 1 ABOUT HERE}

Measures

An online questionnaire was developed with items that are predominantly taken from existing validated instruments. When necessary, these were adapted to the Dutch situation, with a focus on the use of DLMs in educational practices. For all multi-item scales Cronbach's alpha was calculated as a measure of internal consistency. Table 2 summarizes the characteristics of each scale.

INSERT TABLE 2 ABOUT HERE

\section{Results}

Direct relationships 
The results of the bivariate correlations between the variables in the different models are shown in Table 3. The same table also contains the mean score and standard deviation for each variable. Strong direct relationships seem to exist primarily between ICT policy and the three dimensions of transformational leadership, between the dimensions of transformational leadership among themselves and between the three proximal variables.

\section{INSERT TABLE 3 ABOUT HERE}

\section{Path analysis}

Structural equation modelling was used to test the relative fit of three nested models, which differ in the number of direct relationships between the leadership dimensions and professionalization on the one hand and subjective norm, self-efficacy and attitude on the other hand. Structural equation modeling (SEM) is a statistical method that enables testing causal relationships among several variables. The method incorporates factor analysis as well as regression analysis. Factor analysis is used in SEM to model latent constructs based on several measured variables. In SEM causal relationships are not tested using the measured variables as such, but rather with a latent (or underlying) representation of the construct of interest. A first step in a SEM analysis consists of modeling these latent constructs. The second step in SEM is testing the actual causal relationships using path analysis (which is based on regression analysis). As SEM captures the measurement error in the model, a major advantage of this technique is that the structural relationships between the variables are measured more accurately.

We present the models with incremental complexity and their path parameters in Figures 4 . Table 4 shows several fit indices for the tested models. Although these fit indices provide an estimate of the absolute fit of the models, given the focus of this study, differences in fit are of main interest here. The SEM analyses were conducted using AMOS 19. Model fit was evaluated using the $x^{2}$ statistic, which is lower as model fit improves. As the $x^{2}$ statistic rapidly increases with model complexity and sample size, several other measures of model fit are reported. First, the comparative fit index (CFI), for which values between .90 and .94 indicate good fit and values of .95 and higher indicate very good fit. Second, the root mean square error of approximation (RMSEA), for which values between .06 and .08 indicate a good fit and values of .05 and less indicate a very close fit (Browne and Cudeck, 1989). To compare the nested models, we calculated chi-squared differences and tested the significance of these differences. These results are also presented in Table 4.

Before the conjectured structural relationships were tested, the fit of the measurement model was tested. For conciseness, we do not report these results. In model 1 a fully mediated relationship is conjectured, meaning that no direct relationships between the transformational leadership dimensions nor professional development activities, nor attitude, self-efficacy and subjective norm exist. In model 2 direct relationships between the transformational leadership dimensions and professional 
development activities are allowed and finally in model 3 relationships between the transformational leadership dimensions and attitude, self-efficacy and subjective norm are allowed as well.

\section{INSERT TABLE 4 ABOUT HERE}

As can be observed in Table 4, the fit of our model does not increase significantly when allowing direct relationships between the transformational leadership dimensions and professional development activities (as is done in model 2). However, in the third step, when additional direct relationships are allowed between all three leadership dimensions and attitude, self-efficacy and subjective norm, the increase in model fit is significant. The final model with the path coefficients is presented in Figure 4.

The results of the path analysis in model 1 (see Table 5) suggest that the relationship between two dimensions of transformational leadership and the intention to use DLMs are mediated by ICT policy (Hypothesis 1a and 1c) and professional development activities (hypothesis 3 ) as well as the proximal variables $(2 a, b, c$ and $4 a, b, c)$. The transformational leadership dimensions are strongly related to each other; vision correlates with individual consideration by .61 and with intellectual stimulation by .67 , and intellectual stimulation with individual consideration by .90 . The relations between the proximal variables and the intention ( $5 a, b, c)$ to use DLMs are strong for attitude (.43), and rather weak for self-efficacy (.17) and subjective norm (.14). In addition, strong direct effects are found of ICT policy on the self-efficacy and subjective norm regarding teachers' use of DLMs in class; hypothesis $2 \mathrm{a}$ and $2 \mathrm{c}$ are thus confirmed. ICT policy also has a significant direct relation with attitude, although weaker than with the other two proximal variables. Hypothesis $2 b$ can thus also be confirmed.

The results further show that the relationships between only two (hypotheses 1 and 3 ) of the three dimensions of transformational leadership and ICT policy are significant (in all three models). These significant relationships involve the leadership dimensions of vision and intellectual stimulation. The transformational leadership dimension of individual consideration has hardly any effect on the experienced ICT policy, hypothesis $1 \mathrm{~b}$ must therefore be rejected.

The parameters tested in model 2 are shown in Table 5. In comparison with model 1, all three transformative leadership dimensions have an influence on ICT policy and professional development or both. The strongest relation (.38) is found between the leadership dimension vision and ICT policy, followed by intellectual stimulation on both ICT policy and professional development activities (.27). Hypotheses 1a and 1c, are therefore confirmed.

\section{INSERT TABLE 5 ABOUT HERE}

Remarkable and in contrast to our expectations, individual consideration has a negative relationship with professional development activities (-.23).. ICT policy and professional development activities both affect the intention through the mediators self-efficacy, attitude, and subjective norm. ICT-policy influences the three proximal variables less strongly (for hypotheses $2 \mathrm{a}, \mathrm{b}, \mathrm{c}$ respectively 
$.25, .14, .35$ ) than professional development activities do (for the hypotheses $4 a$, b, c respectively .40 , $.37, .35)$.

Model 3, shown in Figure 4, allowing direct relations between the leadership dimensions and the proximal variables, differs only slightly from model 2 , with regard to the path parameters. There is however one clear exception, the relation between ICT-policy and attitude is not significant in this final model. The direct relations from the leadership dimensions with the proximal variables are not significant (7a, b, c till 9a, b, c).

Finally, from the analyses we can conclude that model 3 has the best fit and is the best predictor for teachers' use of DLMs. The discussion will therefore mainly be based on the final model.

\section{INSERT FIGURE 4 ABOUT HERE}

\section{Conclusion and discussion}

The IMBP including several variables at the school level was tested predicting teachers' intention to use DLMs in their teaching practices. The results of the analysis indicate that the intention of teachers to use DLMs is influenced by a complex set of variables. In the model there is not one dominant path influencing teachers' intention to use DLMs. ICT policy is most strongly related with the leadership dimension vision and less with intellectual stimulation. However, ICT policy is not related to attitude, which has in turn the strongest relation with intention. Professional development activities are most strongly affected by intellectual stimulation, which affects the three mediating variables for intention.

The strongest relationships appeared between professional development activities and the three proximal variables, self-efficacy, attitude and subjective norm. This relationship was to be expected from research into ICT professionalization and ICT (Mumtaz, 2000; Pelgrum, 2001; Tondeur et al., 2008; Loogma et al., 2012). No direct relations between the proximal variables and the leadership dimensions were found, this in contrast to research where self-efficacy (Thoonen et al., 2011), attitude and subjective norm (Loogma et al., 2012) were directly related to transformational leadership.

That only two of the three transformational leadership dimensions, namely vision and intellectual stimulation, have a significant impact on ICT policy and that only intellectual stimulation has a positive influence on professional development activities regarding ICT, may correspond to the idea of Marks and Printy (2003). They suggested that transformational leadership is insufficiently unfocused on an organization's goals in order to influence positive organizational outcomes. Also, Leithwood and Jantzi (2006) made a comment on the disappointing effects of transformational leadership as a concept for improvement of school practice, due to the limited impact on student outcomes..Professional development activities are influenced positively through intellectual stimulation, as could be expected, but are negatively influenced by individual consideration. This latter result is puzzling. Thoonen and colleagues (2011) found a similar negative relation in their research between this dimension and professional development activities operationalized as experimenting and reflecting. They conclude that "more support and consideration seems to inhibit teachers' engagement in professional learning activities" (p. 515). Their explanation is as follows: "Showing concern and respect of school leaders for 
teachers' emotions may be interpreted by teachers as tacit agreement of current classroom practice and therefore, may discourage teachers from engaging in experimenting and reflection activities (p. 520)". An explanation that can well be true for the situation and culture in Dutch schools. This is in line with the relatively low perceived subjective norm on using DLMs (Vermeulen et al., 2012) and can be seen as a contribution for this explanation. Perhaps in Dutch schools there is no balance between perceived pressure from the social surroundings on the one hand and showing respect for teachers feelings, encourage or stimulate in trying out new behavior such as using DLMs on the other hand. But more research is needed on this point before jumping into conclusions.

In addition to the above-mentioned problem, Marks and Printy (2003) plead for an integration of transformational leadership and educational leadership. In other words leadership that focuses on vision, individualized consideration, and intellectual stimulus combined with a strong focus on improving student outcomes. Printy (2008) emphasizes the function of communicating a clear vision for the development of social relationships and learning because it serves as a guide for teachers' joint work, extends support for teachers' efforts, and protects teachers from external interference. Applied to the theme of this research, transformational leadership should be combined with focusing on improving student outcomes through the use of modern technologies such as DLMs. Indeed, a guiding policy, which provides teachers with a direction regarding the use of DLMs in the class situation, is important to effectively achieve high results with pupils. The findings of Tondeur et al. $(2008,2010)$ point in this same direction; clear goals and policy development regarding ICT at the school level was one of the stimulating factors for the use of ICT in the classroom.

ICT policy only has direct relationships with two of our proximal variables: self-efficacy and subjective norm. The latter are however less pronounced than attitude in predicting the intention to use DLMs. The link between ICT policy and attitude in the final model appears to be non-significant. A possible explanation is that the official policy in Dutch schools is not integrated in teacher's beliefs about teaching and learning. There is some evidence regarding the major role general pedagogic beliefs play in implementing e-learning didactics (Loogma et al., 2012; Hermans et al., 2008).

Our model comparison approach provided only partial support for our hypothesis that the proximal variables in IMBP as well as professional development activities are determined indirectly by transformational leadership. Although no direct relationships were found between the transformational leadership dimensions and self-efficacy, attitude and subjective norm, the statistical analysis suggests that a model allowing direct relations between some of the variables provides a better fit. The path coefficients indicate that two relationships might be responsible for this improved fit, namely the direct effect of individual consideration and intellectual stimulation on professional development activities. Although these relationships were not conjectured, a possible explanation for the first relationship, which is negative, might be that individual consideration hinders, because there is too much compassion with individual needs (Leithwood and Jantzi, 2006). Rather than external stimulation, previous research showed that teachers' personal entrepreneurship was an important predictor of teachers' intention to use DLMs (Van Acker et al., 2011). The second relationship, between intellectual stimulation and professional development activities, might indicate that teachers' general attitude towards professionalization becomes more favorable because of the intellectual stimulation school 
managers provide. As such, a specific influence of intellectual stimulation may thus be explained by ICT policy, while a general trend towards professionalization might also be triggered as indicated by the direct relationship.

Together these results could indicate that beside the tested variables in this study, other influencing variables mediate between leadership and the proximal variables. For instance the organizational culture of the school or the norms and values that prove to play a major role in innovation processes and innovative behavior (Hargreaves and Fink, 2006). Another possible mediating variable is school learning climate and professional communities. Sebastian and Allensworth (2012) found in their path analyses that only learning climate mediated between leadership and the quality of instruction by teachers. Professional communities are related to teachers learning and working together and developing new practices (Printy, 2008); leadership should facilitate these communities. Future research could look deeper into the mediating relationships of these distal variables in relation to the use of DLMs in pedagogical practices.

This research has some limitations. First, it is not the behavior itself (via self-report or actual behavior) under investigation, but the intention to use DLMs. Without an intention to use DLMs there will be no behavior, therefore it is an important factor to take into consideration. However, between intention and actual use there is still much room for all kinds of distortions, and therefore in future research the model should be expanded with self-reported or actual behavior. A second limitation concerns a part of the operationalization. In the developed model the scale for ICT policy is constructed with only two items.. For a more reliable measurement of this concept, it is desirable to construct a scale with more than two items. A third limitation is the number of distal variables. Only variables related to leadership were included. It is conceivable that the effects found here change as other distal context variables such as student population, school size, school culture, learning climate or experienced personnel policy are added.

Despite the limitations, we can conclude that with the variables chosen here, the results of path analysis confirm the applicability of the IMBP for the topic of using DLMs in pedagogical practices. Future research should further explore the concept of educational leadership combined with transformational leadership, and expand the model with other organizational variables. Further research should also proceed at the level of the student outcomes to gain more insights in the whole chain from organizational variables, through teacher variables and how this affects student behavior and educational outcomes.

For the development of the teaching practices these research findings imply that two dimensions of transformational leadership (vision and intellectual stimulation) through a clear ICT policy and targeted professional development activities, strengthen the self-efficacy, attitude, and subjective norm regarding the use of DLMs by teachers. This influence from a chain of environmental variables on the three proximal variables will, in accordance with the model tested here, affect teachers' intention to use DLMs. 


\section{References}

Ajzen I (1991) The theory of planned behavior. Organizational Behavior and Human Decision Processes, 50, 179-211.

Aryee S, Walumbwa FO, Zhou Q and Hartnell CA (2012) Transformational Leadership, Innovative

Behavior, and Task Performance: Test of Mediation and Moderation Processes. Human Performance, 25(1): 1-25.

Bandura A (1997) Self-efficacy: The exercise of control. New York: W. H. Freeman and Company. Bass BM (1985) Leadership and performance beyond expectations. New York, NY: Free Press.

Bass BM and Avolio BJ (1994). Improving organizational effectiveness through transformational leadership. Thousand Oaks, CA: Sage.

Browne MW and Cudeck R (1989) Single sample cross-validation indices for covariance structures. Multivariate Behavioral Research, 24, 445-455.

Bush T and Glover D (2003) School leadership: concepts and evidence. Nothingham, National College for School Leaderhip

Carmeli A and Schaubroeck J (2007) The influence of leaders' and other referents' normative expectations on individual involvement in creative work. The Leadership Quarterly, 18, 35-48.

Chen M, Lin C, Lin H and McDonough E (2012) Does transformational leadership facilitate technological innovation? The moderating roles of innovative culture and incentive compensation. Asia Pacific Journal Of Management, 29(2), 239-264.

Cosner S (2011) Teacher learning, instructional considerations and principal communication: lessons from a longitudinal study of collaborative data use by teachers. Educational Management Administration \& Leadership 39(5) 568-589.

De Jong JPJ and den Hartog DN (2007) Leadership and employees' innovative behaviour. European Journal of Innovation Management, 10(1), 41-64

Farr F and Ford C (1990) "Individual innovation". In West MA and Farr JL (Eds), Innovation and Creativity at Work: Psychological and Organisational Strategies, Wiley, Chichester.

Fishbein M (2000) The role of theory in HIV prevention. AIDS Care, 12, 273-278.

Fishbein M and Ajzen I (2010) Predicting and changing behavior: The reasoned action approach. New York: Psychology Press

Geijsel FP, Sleegers PJC and Van den Berg RM (1999) Transformational leadership and the implementation of large-scale innovation programs. Journal of Educational Administration, 37, 309-328.

Geijsel FP, Sleegers PJC, Stoel RD and Krüger ML (2009) The Effect of Teacher Psychological, School Organizational and Leadership Factors on Teachers' Professional Learning in Dutch Schools. The Elementary School Journal 109(4), 406-427.

Gong Y, Huang J and Farh J (2009) Employee learning orientation, transformational leadership, and employee creativity: The mediating role of employee creative self-efficacy. Academy of Management Journal, 52, 765-778. 
Gronn P (2000) Distributed Properties, A New Architecture for Leadership. Educational Management Administration \& Leadership, 28(3), 317-338.

Hagger MS and Armitage CJ (2004) The influence of perceived loci of control and causality in the theory of planned behavior in a leisure-time exercise context. Journal of Applied Biobehavioral Research, 9, 45-64.

Hargreaves A and Fink D (2006) Sustainable Leadership. San Francisco, Jossey- Bass.

Hermans RR, Tondeur JJ, van Braak JJ and Valcke MM (2008) The impact of primary school teachers' educational beliefs on the classroom use of computers. Computers and Education, 51(4), 1499-1509.

Janz NK and Becker MH (1984) The health believe model: A decade later. Health Education Quarterly, 5, 34-41.

Kennisnet (2011) Vier in Balans Monitor 2011. Zoetermeer: Kennisnet. (Four in balance monitor. Zoetermeer; Knowledge Network)

Kreijns K, Van Acker F, Vermeulen M and van Buuren H (2013). What stimulates teachers to integrate ICT in their pedagogical practices? The use of digital learning materials in education. Computers in Human Behavior, 29(1), 217-225.

Kwakman, K. (1999). Leren van Leraren tijdens de beroepsloopbaan: Studies naar de professionaliteit op de werkplek in het voortgezet onderwijs. (The learning of teachers during work; studies to the professionalism of the learning environment in secondary education) Unpublished doctoral dissertation. Nijmegen: Katholieke Universiteit Nijmegen.

Law $\mathrm{N}$ and Chow A (2008) Teacher characteristics, contextual factors, and how these affect the pedagogical use of ICT. In: Law N, Pelgrum RJ and and Plomp TJ (Eds.), Pedagogy and ICT use in schools around the World. Findings from the IEA SITES 2006 study, Springer/Comparative Education Research Centre, The University of Hong Kong pp. 181-203.

Leithwood KA and Jantzi D (2006) Transformational school leadership for large scale reform: Effects on students, teachers, and their classroom practices. School Effectiveness and School Improvement, 17, 201-227.

Leithwood KA, Jantzi D and Mascall B (2002) A framework for research on large scale reform. Journal of Educational Change, 3, 7-33.

Leithwood KA and Mascall B (2008) Collective Leadership Effects on Student Achievement. Educational Administration Quarterly, 44(4), 529-561.

Loogma K, Kruusvall J and Ümarik M (2012) E-learning as innovation: Exploring innovativeness of the VET teachers' community in Estonia. Computers and Education, 58(2), 808-817.

Marks HM and Printy SM (2003) Principal leadership and school performance: An integration of transformational and instructional leadership. Educational Administration Quarterly, 39, 370-397.

Mumtaz S (2000) Factors Affecting Teacher's Use of Information and Communications Technology: a Review of the Literature. Journal of Information Technology for Teacher Education, 9, 319-342. OCW (2009). Brief aan de Tweede Kamer der Staten-Generaal. (Letter to the parliament) Opgehaald februari 10, 2011, http://www.minocw.nl/documenten/ Wikiwijs Stimulering open leermiddelen 115373.pdf. 
OECD (2010) PISA 2009 Results: What Makes a School Successful? Resources, Policies and Practice. Volume IVs. Organization for Economic Co-operation and Development. OECD Publishing,

Pelgrum WJ (2001) Obstacles to the Integration of ICT in Education: Results from a Worldwide Educational Assessment. Computers and Education, 37, 163-178.

Pieterse AN, van Knippenberg D, Schippers M and Stam D (2010) Transformational and transactional leadership and innovative behavior: The moderating role of psychological empowerment. Journal of Organizational Behavior, 31, 609-623.

Printy SM (2008) Leadership for Teacher Learning: A Community of Practice Perspective. Educational Administration Quarterly, 44(2), 187-226.

Quinn RE, Fearman S, Thompson MP and McGrath MR (1996) Becoming a Master Manager: A Competency Framework. John Willey and Sons, Inc., New York

Robinson VJ, Lloyd CA and Rowe KJ (2008) The Impact of Leadership on Student Outcomes: An Analysis of the Differential Effects of Leadership Types. Educational Administration Quarterly, 44(5), 635-674.

Sang G, Valcke MM, Van Braak JJ, Tondeur JJ and Zu C (2011) Predicting ICT integration into classroom teaching in Chinese primary schools: exploring the complex interplay of teacherrelated variables. Journal of Computer Assisted Learning, 27, 160-172

Sebastian J and Allensworth E (2012) The Influence of Principal Leadership on Classroom Instruction and Student Learning. Educational Administration Quarterly, 48(4), 626-663.

Stoll L, Bolam R, McMahon A, Wallace A, and Thomas S (2006) Professional learning communities: a review of the literature. Journal of Educational Change, 7, 221-258

Thoonen EJ, Sleegers PJC, Oort FJ, Peetsma TDD and Geijsel FP (2011) Motivation, Organizational Factors, and Leadership Practices. How to Improve Teaching Practices : The Role of Teacher. Educational Administration Quarterly 47(3), 496- 536.

Tondeur JJ, Van Braak JJ and Valcke MM (2007) Curricula and the use of ICT in education: Two worlds apart? British Journal Of Educational Technology, 38(6), 962-976.

Tondeur JJ, Valcke MM and Van Braak JJ (2008) A multidimensional approach to determinants of computer use in primary education: teacher and school characteristics. Journal of Computer Assisted Learning, 24, 494-506.

Tondeur JJ, Valcke MM and Van Braak JJ (2010) De invloed van leraar- en schoolkenmerken op het gebruik van ICT in het lager onderwijs. (The influence of teacher and schoolfactors on the use of ICT in primary education) Pedagogische studiën, 2, 91-104.

Timperley H, Wilson A, Barrar H and Fung I (2007) Teacher Professional Learning and Development: Best Evidence Synthesis Iteration Wellington, New Zealand: Ministry of Education http://educationcounts.edcentre.govt.nz/goto/BES Page 3.

Van Acker F, Kreijns K, van Buuren $\mathrm{H}$ and Vermeulen $\mathrm{M}$ (2011) Why teachers use digital learning materials: The role of self-efficacy, subjective norm and attitude. Education and Information Technologies. online. doi 10.1007/s10639-011-9181-9 
Van Buuren H, Van Acker F, Kreijns K and Verboon P (2010). Rapport Nulmeting 2009 Wikiwijs.

Onderzoek onder leerkrachten in het primair onderwijs, voorbereidend middelbaar beroepsonderwijs, voortgezet onderwijs en middelbaar beroepsonderwijs naar gebruik, ontwikkeling, delen van digitale leermaterialen en professionaliseringsbehoeften bij de start van Wikiwijs. (Pre research Wikiwijs. Survey of teachers in primary education, secondary education and secondary VMBO, vocational education to use, development, parts of digital learning materials and their professionalization needs at the start of Wikiwijs) Heerlen: OU.

Van der Heijden, B.I.J.M. (2003), "Organisational influences upon the development of occupational expertise throughout the career", International Journal of Training and Development, 7(3), $142-65$

Vanderlinde R, van Braak JJ and Dexter S (2012) ICT policy planning in a context of curriculum reform: Disentanglement of ICT policy domains and artifacts. Computers and Education, 58, $1339-1350$.

Van Kessel N, van der Neut AC, Uerz D and Vermeulen M (2004) Leren voor de toekomst: 7 jaar onderwijs and ICT. (Learning for the future: 7 years and ICT education) IVA Tilburg/ITS Nijmegen. The Netherlands.

Vermeulen M, Van Acker F, Kreijns K and van Buuren H (2012) Leraren en hun intentie tot het gebruik van digitale leermaterialen in hun onderwijspraktijk. (Teachers and their intention to the use digital learning materials in their educational practice). Pedagogische studiën, 89(3), 159-173.

Yang SC and Huang YF (2008) A study of high school English teachers' behavior, concerns and beliefs in integrating information technology into English instruction. Computers in Human Behavior, 24, 1085-1103.

Yukl G (1998) Leadership in organizations (4th ed.). Englewood Cliff, NJ: Prentice Hall. 
Table 1. Characteristics of the research group: gender, age and type of school

\begin{tabular}{l|cccc}
\hline & Primary & Secondary & Vocational & Total \\
\hline Men \% & $20.49 \%$ & $57.23 \%$ & $57.23 \%$ & $40.28 \%$ \\
Age $(M)$ & 44.49 & 45.92 & 46.17 & 45.27 \\
\hline Total & $366(47.41 \%)$ & $317(41.06 \%)$ & $89(11.53 \%)$ & 772 \\
\hline
\end{tabular}


Table 2. Overview of the scales used, answer categories, Cronbach's alpha, the source of the scale.

\begin{tabular}{|c|c|c|}
\hline $\begin{array}{l}\text { Scale and } \\
\text { source }\end{array}$ & $\alpha$ & $\begin{array}{l}\text { Range } 1-7 \\
\text { Items }\end{array}$ \\
\hline Intention & .95 & $\begin{array}{l}\text { Please indicate to what extent the following statements apply to you: } \\
\text { a. I plan to use digital learning materials during class regularly1 } \\
\text { b. I intend to use digital learning materials during class regularly } \\
\text { c. I think I should use digital learning materials during class regularly } \\
\text { d. I expect to use digital learning materials during class regularly } \\
\text { Answer categories: } 1 \text { = 'absolutely unlikely' ... } 7 \text { = 'extremely likely' }\end{array}$ \\
\hline $\begin{array}{l}\text { Self-efficacy } \\
\text { Geijsel, et al. } \\
\text { (2009) }\end{array}$ & .94 & $\begin{array}{l}\text { a. I am able to regular use digital learning effectively in my classes } \\
\text { b. I am satisfied with the way I regularly use in my digital learning lessons } \\
\text { c. I feel successful in the deployment of digital learning materials regularly in my classes. } \\
\text { d. I am confident enough in the regular use of digital learning in my classes } \\
\text { Answer categories: } 1 \text { = 'completely not true' ... } 7 \text { = 'completely true' }\end{array}$ \\
\hline $\begin{array}{l}\text { Attitude } \\
\text { Vermeulen, et al. } \\
\text { (2012) }\end{array}$ & .97 & $\begin{array}{l}\text { For me, to use digital learning materials during class regularly is } \ldots \\
\text { a. } 1 \text { = 'valuable' }-7=\text { 'worthless' } \\
\text { b. } 1=\text { 'meaningful' }-7=\text { 'meaningless' } \\
\text { c. } 1 \text { = 'useless' }-7 \text { = 'useful' } \\
\text { d. } 1 \text { = 'boring' }-7 \text { = 'fun' } \\
\text { e. } 1=\text { 'dull' }-7=\text { 'exciting' } \\
\text { f. } 1 \text { = 'fantastic' }-7 \text { = 'horrible' } \\
\text { Answers by bipolar scales }\end{array}$ \\
\hline $\begin{array}{l}\text { Subjective norm } \\
\text { Vermeulen, et al. } \\
(2012)\end{array}$ & - & $\begin{array}{l}\text { All things considered, to what extent do you experience social pressure of your school } \\
\text { leadership, team leaders, parents etc. in order to use in your lessons regularly DLMs. } \\
\text { Answer categories: } 1 \text { = 'absolutely no pressure' } \ldots 7 \text { = 'extremely much pressure' }\end{array}$ \\
\hline $\begin{array}{l}\text { Professional } \\
\text { development } \\
\text { Kwakman (1999) }\end{array}$ & .86 & $\begin{array}{l}\text { Acquiring knowledge and skills digital learning materials... } \\
\text { a. by consulting the internet } \\
\text { b. by talking about the use of digital learning materials with colleagues in school } \\
\text { c. by experimenting with digital learning in lessons } \\
\text { d. by asking how students experience the way you use digital learning materials in class } \\
\text { e. by reflecting on the strength and weaknesses of your use of digital learning materials } \\
\text { f. by following this training and courses." } \\
\text { g. by attending presentations on this subject in your school given by educational ICT experts. } \\
\text { Answer categories: } 1=\text { 'never' } \ldots 7 \text { = 'always' }\end{array}$ \\
\hline $\begin{array}{l}\text { ICT policy } \\
\text { Partly based on } \\
\text { Tondeur et al. } \\
(2008,2010) .\end{array}$ & .84 & $\begin{array}{l}\text { a. There is an ICT-policy plan that is actually performed. } \\
\text { b. The management has a clear view on the use of digital learning materials } \\
\text { Answer categories: } 1 \text { = 'not applicable' } \ldots 7 \text { = 'fully apply' }\end{array}$ \\
\hline $\begin{array}{l}\text { Trans- } \\
\text { formational } \\
\text { leadership: } \\
\text { vision } \\
\text { Geijsel, et al. } \\
\text { (2009) }\end{array}$ & .96 & $\begin{array}{l}\text { The leadership of my school } \\
\text { a. uses all possible occasions to stipulate the vision of the school to the team, students and } \\
\text { others. } \\
\text { b. refers explicitly to school goals during decision-making processes } \\
\text { c. clarifies for the team the relationship between the vision of school and various initiatives } \\
\text { taken from the board, partnerships or national government } \\
\text { d. describes in a clear manner, based on the vision of the school the current problems } \\
\text { e. outlines at meetings what the consequences are of the vision of the school for the current } \\
\text { ins and outs. } \\
\text { Answer categories: } 1 \text { = 'not applicable' ... } 7 \text { = 'fully apply' }\end{array}$ \\
\hline
\end{tabular}




\begin{tabular}{|c|c|c|}
\hline $\begin{array}{l}\text { Scale and } \\
\text { source }\end{array}$ & $\alpha$ & $\begin{array}{l}\text { Range } 1-7 \\
\text { Items }\end{array}$ \\
\hline $\begin{array}{l}\text { Trans- } \\
\text { formational } \\
\text { leadership: } \\
\text { individual } \\
\text { consideration } \\
\text { Geijsel, et al. } \\
\text { (2009) }\end{array}$ & .95 & $\begin{array}{l}\text { The leadership of my school } \\
\text { a. takes the views of individual teachers seriously } \\
\text { b. shows appreciation when a teacher take the initiative for improving education. } \\
\text { c. listens carefully to the ideas of team members } \\
\text { d. helps teachers to express their emotions } \\
\text { e. has an eye and ear for problems experienced by teachers when introducing innovations } \\
\text { Answer categories: } 1 \text { = 'not applicable' ... } 7 \text { = 'fully apply' }\end{array}$ \\
\hline $\begin{array}{l}\text { Trans- } \\
\text { formational } \\
\text { leadership: } \\
\text { intellectual } \\
\text { stimulus } \\
\text { Geijsel, et al. } \\
\text { (2009) }\end{array}$ & .97 & $\begin{array}{l}\text { The leadership of my school } \\
\text { a. helps teachers to express and clarify their personal ideas about teaching } \\
\text { b. encourages teachers to try out new things in line with their interests } \\
\text { c. helps teachers to reflect on new experiences that they acquire as a teacher } \\
\text { d. encourages teachers to think about how to improve our institution / department } \\
\text { e. encourages the search for and discussing of new information and ideas relevant to the } \\
\text { development of the institution / program } \\
\text { f. involves individual teachers in an ongoing debate about their personal professional goals } \\
\text { g. encourages teachers to experiment with new teaching methods } \\
\text { h. creates ample opportunities for teachers to develop professionally } \\
\text { Answer categories: } 1 \text { = 'not applicable' ... } 7 \text { = 'fully apply' }\end{array}$ \\
\hline
\end{tabular}

\footnotetext{
${ }^{1}$ regularly is defined as 'a few times a week during the school year'
} 
Table 3. Correlation matrix; with in the second column the mean (M) and the standard deviation (SD) $(\mathrm{n}=772)$.

\begin{tabular}{|c|c|c|c|c|c|c|c|c|c|}
\hline & $M(S D)$ & 1 & $2 \mathrm{a}$ & $2 \mathrm{~b}$ & $2 \mathrm{c}$ & 3 & 4 & $5 a$ & $5 b$ \\
\hline 1. intention & $4.94(1.67)$ & & & & & & & & \\
\hline 2a. self-efficacy & $4.75(1.65)$ & .299 & & & & & & & \\
\hline 2b. attitude & $5.56(0.91)$ & .488 & .394 & & & & & & \\
\hline 2c. subjective norm & $4.13(1.65)$ & .317 & .486 & .333 & & & & & \\
\hline \multicolumn{10}{|l|}{ 3. professional } \\
\hline development & $2.77(0.90)$ & .259 & .334 & .288 & .349 & & & & \\
\hline 4. ICT policy & $4.05(1.54)$ & .113 & .187 & .109 & .261 & .149 & & & \\
\hline \multicolumn{10}{|l|}{$\begin{array}{l}\text { Transformational } \\
\text { leadership: }\end{array}$} \\
\hline 5a. vision & $4.56(1.48)$ & .090 & .171 & .195 & .144 & .129 & .465 & & \\
\hline 5b. individual inspiration & $4.64(1.49)$ & .113 & .111 & .151 & .092 & .074 & .350 & .567 & \\
\hline 5c. intellectual stimulus & $4.66(1.38)$ & .121 & .123 & .191 & .111 & .112 & .406 & .593 & .842 \\
\hline
\end{tabular}

Note: All correlations are significant for $p<.05$. All scores have a range from 1 to 7 . 
Table 4. Fit indices for the three path models and the result of the model comparison

\begin{tabular}{lccccc}
\hline Model & Fit index & & & & Model comparison \\
& CFI & NFI & RMSEA & $X^{2}$ & \\
\hline (1) Fully mediated & .947 & .923 & .051 & 2400.52 & \\
(2) Partial professionalization & .947 & .923 & .051 & 2392.51 & $\Delta X^{2}(3)=7.51, p=.058$ \\
(3) Full partial & .948 & .924 & .051 & 2355.17 & $\Delta X^{2}(12)=45.35, p<.001$ \\
\hline
\end{tabular}


Table 5. Parameters of the three path models.

\begin{tabular}{|c|c|c|c|c|c|}
\hline & relations & & model 1 & model 2 & model 3 \\
\hline & I vision & I individual consideration & .61 & .61 & .61 \\
\hline & I vision & I intellectual stimulation & .67 & .67 & .67 \\
\hline & I individual consideration & I intellectual stimulation & .90 & .90 & .90 \\
\hline $1 \mathrm{a}$ & I vision & ICT policy & .38 & .38 & .39 \\
\hline $1 b$ & I individual consideration & ICT policy & ns & ns & ns \\
\hline $1 c$ & I intellectual stimulation & ICT policy & .25 & .27 & .25 \\
\hline $2 a$ & ICT policy & self-efficacy & .23 & .25 & .27 \\
\hline $2 b$ & ICT policy & attitude & .13 & .14 & ns \\
\hline $2 c$ & ICT policy & subjective norm & .35 & .35 & .37 \\
\hline 3. & ICT policy & professional development & .16 & .11 & .12 \\
\hline $4 a$ & professional development & self-efficacy & .38 & .40 & .39 \\
\hline $4 b$ & professional development & attitude & .36 & .37 & .37 \\
\hline $4 c$ & professional development & subjective norm & .33 & .35 & .35 \\
\hline $5 a$ & self-efficacy & intention & .17 & .17 & .17 \\
\hline $5 b$ & attitude & intention & .43 & .43 & .43 \\
\hline $5 c$ & subjective norm & intention & .14 & .14 & .14 \\
\hline $6 a$ & I vision & professional development & $\begin{array}{c}\text { not } \\
\text { measured }\end{array}$ & ns & ns \\
\hline $6 b$ & I individual consideration & professional development & $\begin{array}{c}\text { not } \\
\text { measured }\end{array}$ & -.23 & -.23 \\
\hline $6 c$ & I intellectual stimulation & professional development & $\begin{array}{c}\text { not } \\
\text { measured }\end{array}$ & .27 & .26 \\
\hline $7 a$ & I vision & self-efficacy & \multicolumn{2}{|c|}{ not measured } & ns \\
\hline $7 b$ & I vision & attitude & \multicolumn{2}{|c|}{ not measured } & ns \\
\hline $7 c$ & I vision & subjective norm & \multicolumn{2}{|c|}{ not measured } & ns \\
\hline $8 a$ & I individual consideration & self-efficacy & \multicolumn{2}{|c|}{ not measured } & ns \\
\hline $8 b$ & I individual consideration & attitude & \multicolumn{2}{|c|}{ not measured } & ns \\
\hline $8 c$ & I individual consideration & subjective norm & \multicolumn{2}{|c|}{ not measured } & ns \\
\hline $9 a$ & I intellectual stimulation & self-efficacy & \multicolumn{2}{|c|}{ not measured } & ns \\
\hline $9 b$ & I intellectual stimulation & attitude & \multicolumn{2}{|c|}{ not measured } & ns \\
\hline $9 c$ & I intellectual stimulation & subjective norm & \multicolumn{2}{|c|}{ not measured } & ns \\
\hline
\end{tabular}

Note: All path parameters are significant for $p<.05$ 


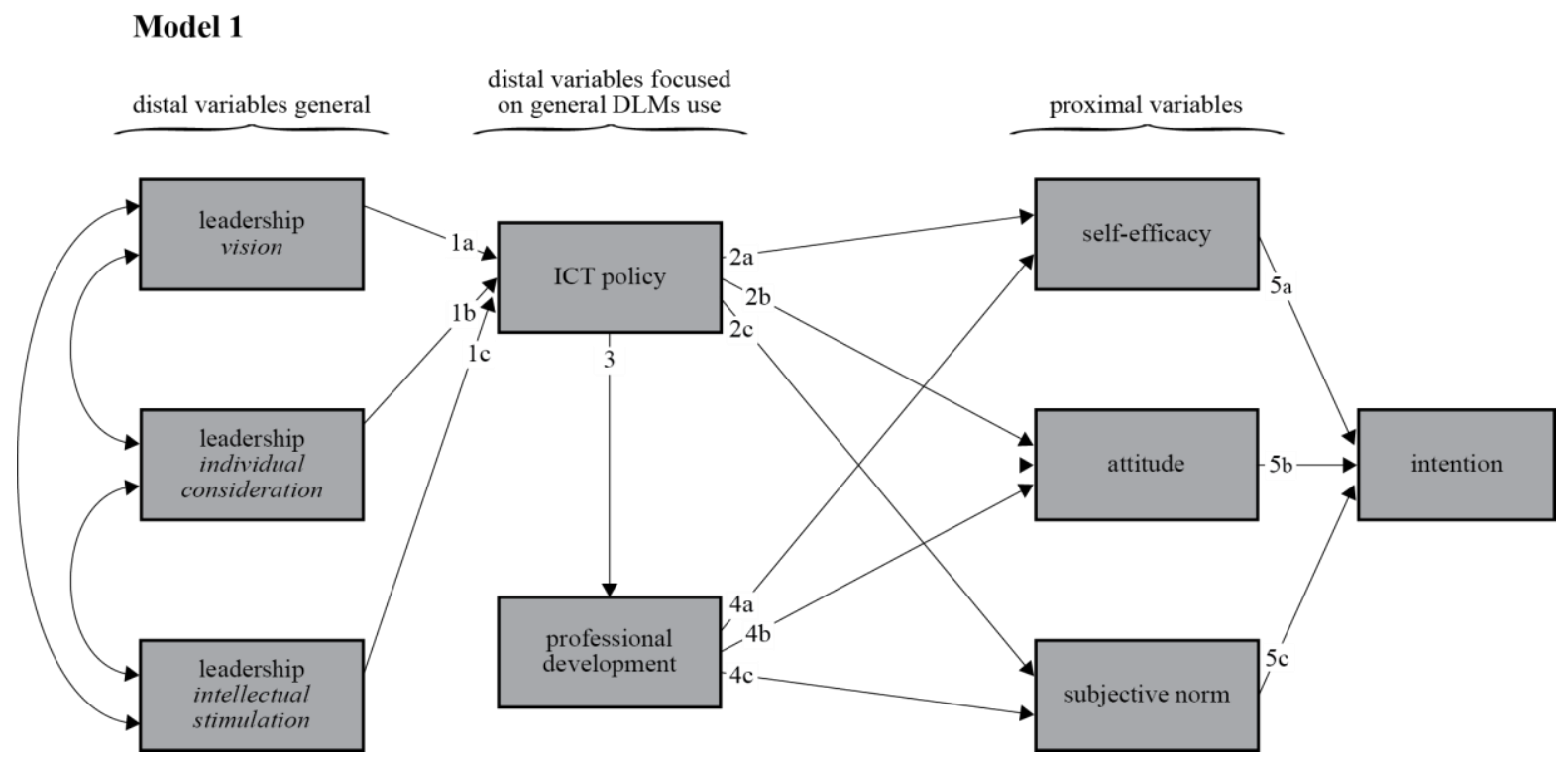

Figure 1. The integrated Model for Behavioral prediction (IMBP) for the use of DLMs; path with direct $(1 a, b, c)$ relation between leadership and ICT policy and indirect relation (3) with professional development with intention to use DLMs 


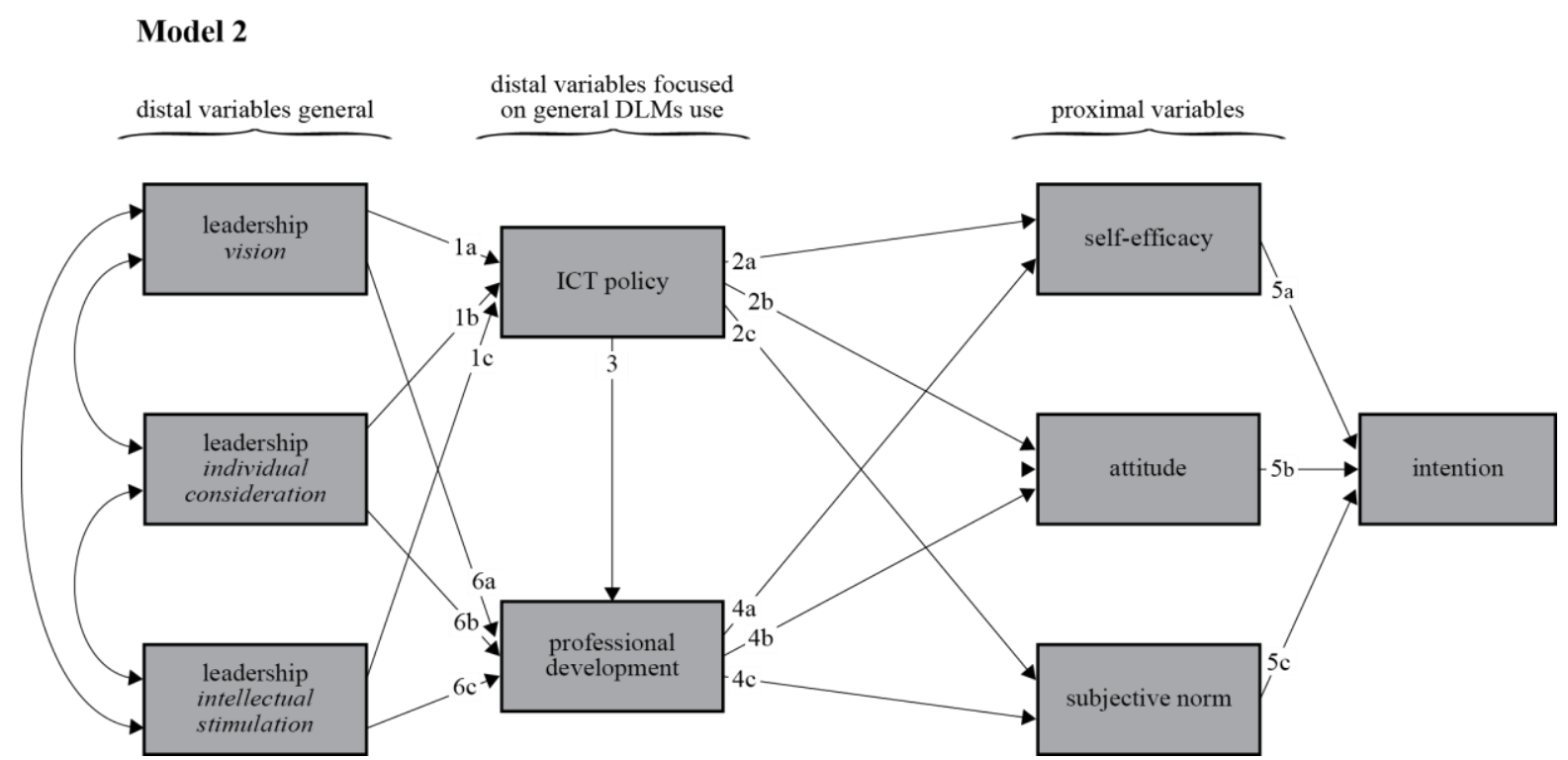

Figure 2. The integrated Model for Behavioral prediction (IMBP) for the use of DLMs; path with direct relation between leadership and ICT policy $(1 \mathrm{a}, \mathrm{b}, \mathrm{c})$ and professional development $(6 \mathrm{a}, \mathrm{b}, \mathrm{c})$ and indirect relation with intention to use DLMs. 
Model 3

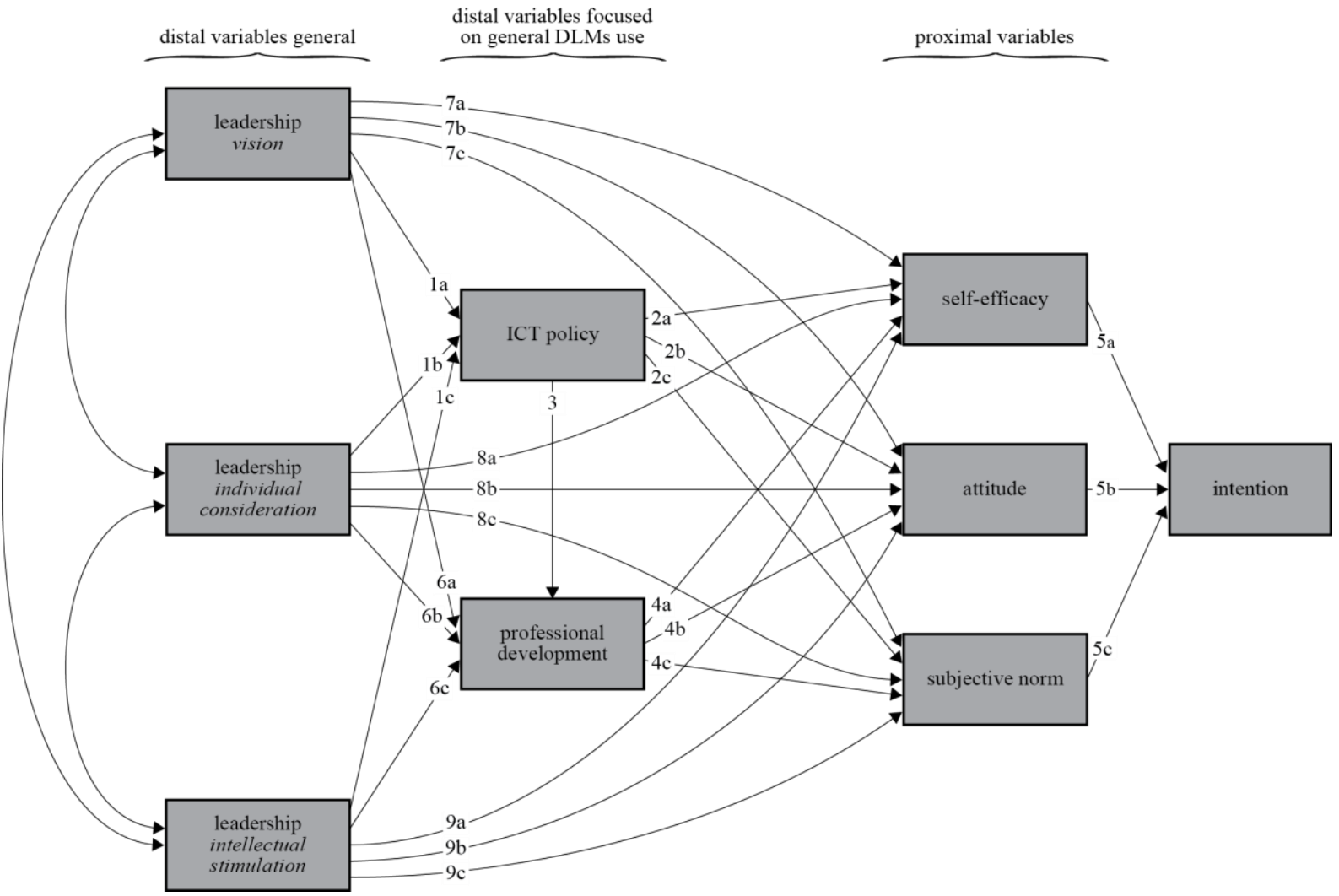

Figure 3. The integrated Model for Behavioral prediction (IMBP) for the use of DLMs path with direct $(6 a, b, c)$ relationships between leadership and professional development and direct (7,a,b,c,8a,b,c, $9 a, b, c)$ and indirect relations with intention to use DLMs 


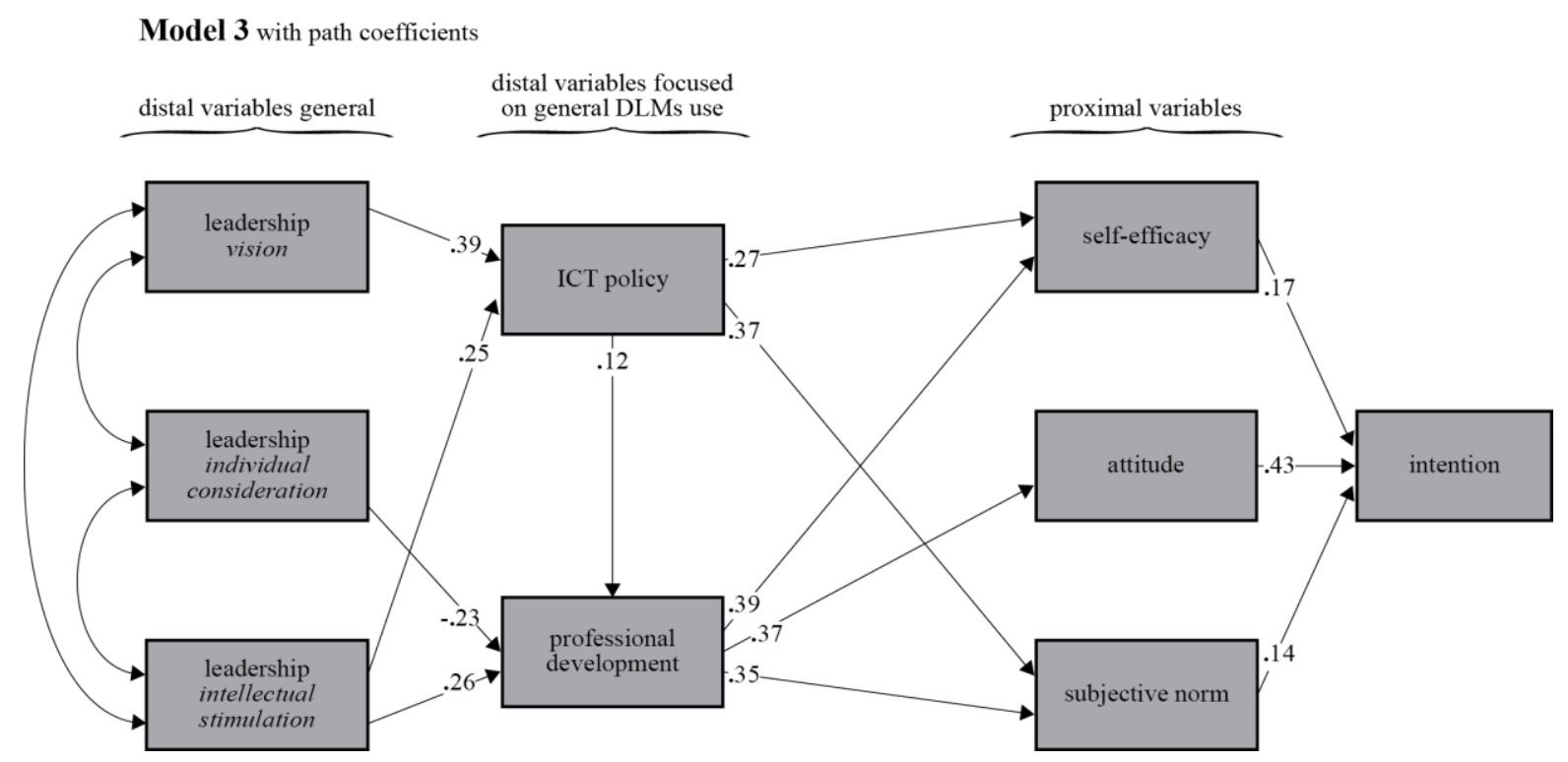

Figure 4. The path coefficients for model 3 the integrated Model for Behavioral Prediction (IMBP) for the use of DLMs, with direct relations from leadership to professional development activities and direct relations from leadership to the proximal variables self efficacy, attitude and subjective norm. Nonsignificant paths were omitted from the diagram. 
